Abstracta Iranica Abstracta Iranica

Revue bibliographique pour le domaine irano-aryen

Volume 27 | 2006

Comptes rendus des publications de 2004

"A second 'Herat Bucket' and its congeners ». Translated by J. M. Rogers, Muqarnas, XXI (2004), pp. 171-179.

Rocco Rante

(2) OpenEdition

Journals

Édition électronique

URL : http://journals.openedition.org/abstractairanica/6128

DOI : 10.4000/abstractairanica.6128

ISSN : 1961-960X

Éditeur :

CNRS (UMR 7528 Mondes iraniens et indiens), Éditions de l'IFRI

Édition imprimée

Date de publication : 15 mai 2006

ISSN : 0240-8910

Référence électronique

Rocco Rante, " «A second 'Herat Bucket' and its congeners ». Translated by J. M. Rogers, Muqarnas, XXI (2004), pp. 171-179. », Abstracta Iranica [En ligne], Volume 27 | 2006, document 243, mis en ligne le 02 janvier 2007, consulté le 25 septembre 2020. URL : http://journals.openedition.org/ abstractairanica/6128 ; DOI : https://doi.org/10.4000/abstractairanica.6128

Ce document a été généré automatiquement le 25 septembre 2020.

Tous droits réservés 


\section{« A second 'Herat Bucket' and its congeners ». Translated by J. M. Rogers, Muqarnas, XXI (2004), pp. 171-179.}

Rocco Rante

1 L'A. propose une ré-interprétation du "Fould Bucket», conservé au Musée de l'Ermitage. Son attribution à un atelier de Herat et sa datation du $12^{\mathrm{e}} \mathrm{s}$.-début du $13^{\mathrm{e}} \mathrm{s}$. par L. T. Giuzalian, sont ici remis en question.

2 L'A. observe d'abord que la technique de dorure du bronze de ce récipient est fréquente en Anatolie centrale vers la deuxième moitié du $13^{\mathrm{e}}$ siècle. Il observe ensuite une série d'éléments décoratifs communes à ce seau et à d'autres objets anatoliens qui l'amènent à conclure à une origine anatolienne du «Fould Bucket ». L'un de ces thèmes est l'image de Bahrām Gūr et Āzāde, plutôt rare sur les métaux. Enfin l'analyse des inscriptions arabes en coufique et nasHīi, incite l'A. à attribuer à cet objet une date postérieure à l'invasion mongole. L'ensemble des données concernant la manufacture et la décoration de l'objet, assez particulier, témoigne de la diversité de l'art islamique dans lequel de multiples traditions se sont croisées.

INDEX

Thèmes : 5.1. Monde iranophone 
AUTEURS

ROCCO RANTE

IFRI - Téhéran 